\title{
Etnofon. Jak udostępniać dokumentalne nagrania muzyki ludowej? \\ Z Jackiem Jackowskim rozmawia Piotr Grochowski
}

\section{Etnofon. How to make folk music recordings available? \\ A conversation between Jacek Jackowski and Piotr Grochowski}

DOI: $10.12775 /$ LL.4.2021.006 | CC BY-ND 4.0

JACEK JACKOWSKI is a musician and ethnomusicologist, and the head of the Phonographic Collection at the Institute of Art of the Polish Academy of Sciences. He specializes in the conservation, digitization and archiving of old sound recordings. He is a field researcher and author of many academic articles on traditional, Catholic and folk religious culture associated with musical behaviours. He also published numerous articles and books on early folk music recordings and their digitization (Zachować dawne nagrania, Warszawa 2014; Polska muzyka tradycyjna - dziedzictwo fonograficzne, t. 1, Warszawa 2017; t. 2, Warszawa 2019), as well as 17 CD albums of folk songs and music from Kashubia, Kurpie, Podhale, Łowicz, Orava, South Wielkopolska and many other regions of Poland. Since $\mathbf{2 0 1 4}$ he has been managing the Etnofon project, the goal of which is to create, develop and maintain a central digital repository of documentary phonographic and film recordings capturing Polish traditional songs and music as well as folk dance.

KEYWORDS: folk music, traditional music, music archives, digital repository, digital humanities, ethnomusicology 
PG: Etnofon ${ }^{1}$ to projekt realizowany przez Instytut Sztuki PAN we współpracy ze stowarzyszeniem Liber pro Arte, który w moim przekonaniu może mieć przełomowe znaczenie dla badań nad polską muzyką ludową. Jest to cyfrowe repozytorium, służące do gromadzenia, opracowywania i udostępniania nagrań muzyki ludowej, które do tej pory były rozproszone po różnych kolekcjach znajdujących się zarówno w instytucjach publicznych, jak i zbiorach prywatnych. Zacznijmy od tego, jaka jest geneza i historia tego projektu.

JJ: Sam pomysł tego typu zasobu powstał już dawno, właściwie równolegle z samą ideą utrwalania tradycji muzycznej w postaci nagrań dźwiękowych, która została przedstawiona w pierwszej dekadzie XX w. przez profesora Adolfa Chybińskiego. Ten wszechstronny muzykolog już w czasach zaborów uważał, że polska kultura musi być utrwalana również za pomocą najnowszych osiągnięć technologii. Drugie nazwisko to Juliusz Zborowski, który swą ideę nagrań na Podhalu określał jako zaczątek „polskiego archiwum fonograficznego”, a później - już w okresie międzywojennym - mówił wręcz o archiwum centralnym. W odróżnieniu od Chybińskiego, który był tylko ideologiem, Zborowski dokonywał nagrań i był pierwszym w Polsce, który tak naprawdę zgromadził ich kolekcję (niewielką, ale jednak pomyślaną jako mający się powiększać zbiór) i część tej kolekcji przetrwała do dziś. Trzecią osobą jest Łucjan Kamieński związany z Poznaniem i jego Regionalne Archiwum Fonograficzne. No i następnie mamy powołane w 1934 r. Centralne Archiwum Fonograficzne, które powstało w strukturach Biblioteki Narodowej w Warszawie i dokumentowało folklor muzyczny obecny na ziemiach II Rzeczpospolitej. Później następuje tragedia II wojny światowej, która obraca w niwecz cały ten dorobek, ale nie obraca $\mathrm{w}$ niwecz samej idei. W roku 1945 mamy bowiem natychmiastowy powrót do prac dokumentacyjnych, realizowanych przez Jadwige i Mariana Sobieskich, którzy wykorzystali ówczesny system władzy i pewną koniunkturę polityczną, ale - co trzeba podkreślić - nie ulegli, nie usługiwali temu systemowi. Zorganizowana przez nich Akcja Zbierania Folkloru Muzycznego polegała na ratowaniu tego, co zostało utracone w czasie wojny, a jej działania objęły całą ówczesną mape Polski. Dzięki współpracy technologicznej z Polskim Radiem samochody z odpowiednim sprzętem ruszyły niezależnie w kilka kierunków i przez cztery lata (bo tyle formalnie trwała akcja) w ten sposób zbierano folklor muzyczny. Tak powstał zrąb tej największej kolekcji nagrań, której koncepcja ideowa i merytoryczna została wypracowana przez Instytut Sztuki Polskiej Akademii Nauk (dawniej Państwowy Instytut Sztuki) będący też jej depozytariuszem.

Po zakończeniu tej akcji (trzeba jednak dodać, że później podobne formy badań organizowano jeszcze w ramach obozów studenckich na Katolickim Uniwersytecie Lubelskim oraz prac dokumentacyjnych Roderyka Langego) zwłaszcza w latach 6o., 70., 80. i 90. - w zasadzie następuje powrót do indywi-

1 Pełna nazwa projektu, w ramach którego powstaje Etnofon, brzmi „Polska muzyka tradycyjna - dziedzictwo fonograficzne. Stan aktualny, zachowanie, udostępnianie”. 
dualnych wysiłków. Ale to nie są już próby czy epizody, tylko konkretna i regularna działalność dokumentacyjna muzealników, etnomuzykologów oraz wielu zapaleńców i miłośników folkloru, którzy w takim zbieractwie w jakiś sposób realizują też swoje pasje. W związku z rozwojem technologii bardzo wielu takich dokumentalistów korzystało z magnetofonów, później z cyfrowych urządzeń do zapisu dźwięku; i to się dzieje do dziś. Doszliśmy więc do wniosku, że należy zmienić punkt ciężkości naszych zainteresowań i przesunąć go z organizowania akcji dokumenujących folklor muzyczny na eksplorację tego już istniejącego dorobku, o którym bardzo mało wiemy. I to się okazało słuszne. W 2014 r. spróbowałem dokonać takiej pierwszej, ogólnej oceny stanu posiadanych źródeł; wtedy powstał duży artykuł opublikowany w Raporcie o stanie tradycyjnej kultury muzycznej wydanym z okazji Roku Kolberga, gdzie pisałem o niemal wszystkich znanych wówczas kolekcjach nagrań muzyki ludowej i próbowałem je jakoś sklasyfikować, dzieląc na zbiory radiowe, muzealne, instytucji naukowych, instytucji regionalnych, zbiory prywatne. I to był właściwie taki etap „0” naszego projektu, taka pierwsza refleksja, która pokazała, że tak naprawdę nie ma białych plam w dokumentacji folkloru muzycznego. Ta dokumentacja jest, ale trzeba ją odnaleźć, zidentyfikować, zweryfikować i zinwentaryzować - i to nawet nie same nagrania, ale wiedzę o nich. Tak się zaczęła przygoda z Etnofonem, którego pierwszym krokiem było takie - można powiedzieć - „skontrum”.

PG: Etnofon to projekt rozwojowy. Jak wygląda jego aktualne zaawansowanie? Ile nagrań z ilu kolekcji jest już dostępne i jak rysują się perspektywy wprowadzania dalszych nagrań i kolekcji?

JJ: Na dzień dzisiejszy mamy około 30 większych lub mniejszych podmiotów, których kolekcje wchodzą do tej bazy. Warto przy tym podkreślić, że wielkość tych kolekcji bywa diametralnie różna. Czasami są to mikroskopijne zbiory, ale bardzo cenne, jak np. nagrania profesora Jana Mirosława Kasjana czy arcyciekawego człowieka, Wacława Tuwalskiego, który zostawił swoją spuściznę w Muzeum Regionalnym w Woli Osowińskiej. Na drugim biegunie leżą z kolei ogromne zasoby takich instytucji jak KUL, Instytut Sztuki PAN czy Muzeum w Rzeszowie, gdzie zdeponowany jest m.in. zbiór nagrań Franciszka Kotuli. W momencie kiedy rozmawiamy, w bazie mamy ok. 150 ooo utworów, zarówno wokalnych, jak i instrumentalnych, które zostały zarejestrowane na ponad 7 ooo nośników dźwięku lub dźwięku i obrazu od ponad 13500 artystów. Na te cyfry składają się utwory z tych wszystkich wspomnianych kolekcji, ale poszczególne kolekcje są na różnych etapach opracowywania i wprowadzania do bazy. Przykładowo, same zbiory Instytutu Sztuki PAN są wprowadzone do bazy dopiero mniej więcej w trzech czwartych; a do wprowadzenia pozostaje jeszcze np. ogromny zasób kaset magnetofonowych czy zbiory na innych nośnikach.

Ogólnie można powiedzieć, że nasze prace przebiegają dwutorowo. Pierwsza rzecz, to wyszukiwanie kolekcji. Samo odnalezienie jakiejś kolekcji, nie oznacza jednak, że od razu jest ona „brana na warsztat”. Najpierw trzeba 
dokonać oceny takiej kolekcji, by potem zdobyć fundusze na jej opracowanie; czasami okazuje się, że jej stan techniczny wymaga wykorzystania zaawansowanej aparatury i zabiegów, np. szczególnego sprzętu do odczytu czy procesu fumigacji (odgrzybiania). Dopiero później następuje odtworzenie, cyfryzacja, identyfikacja, weryfikacja, indeksacja, deskrypcja, wprowadzanie kolekcji do bazy, archiwizacja i wiele innych zabiegów. Nie jest jednak tak, że wszystkie kolekcje są wprowadzane do bazy równolegle. Doszliśmy do wniosku, że lepiej będzie w pierwszej kolejności wzorcowo opracować i umieścić w Etnofonie kilka dużych kolekcji - chodzi o to, że w ramach projektu pracujemy m.in. nad standardem deskrypcji i opracowania tego typu zasobów, a tym samym różnorodność kolekcji ma ogromne znaczenie dla naszych doświadczeń i kształtowania tych standardów. Można wyobrazić sobie taki słupkowy wykres, gdzie każdy słupek to inna kolekcja, której zasoby będą się „buforowały” w naszej bazie w innym tempie. Są kolekcie bardzo proste i są kolekcje bardzo skomplikowane. Są zbiory składające się z setek nośników, których opracowywanie przebiega względnie szybko, bo ich twórcy zadbali o przygotowanie odpowiednich opisów, z których my wytwarzamy metadane, ale są zbiory liczące kilka nośników, nad którymi trzeba pracować bardzo długo. Tak więc dzięki Etnofonowi nasza wiedza o istniejących w Polsce kolekcjach etnomuzycznych na pewno będzie się szybko poszerzać, ale ich umieszczenie w bazie zajmie sporo czasu, chyba że zdarzy się cud i otrzymamy jakieś potężne środki finansowe, pozwalające na zatrudnienie większego zespołu badawczego, który mógłby opracowywać te zbiory w szybszym tempie. Aktualna sytuacja pandemiczna też stwarza sporo przeszkód, na szczęście Etnofon pozwala na realizację wielu zadań w trybie zdalnym.

W tym miejscu trzeba by też powiedzieć, że ten projekt jest dużym wyzwaniem i w pewnym sensie burzy dotychczasowy sposób patrzenia na tego typu materiały. Problem polega na tym, że agregowane w ramach Etnofonu zbiory są bardzo różne i w różny sposób opracowywane. Często natrafiamy na takie zbiory, które na początku trudno w ogóle ocenić. W naszej pracy zdarzają się takie sytuacje - skądinąd pasjonujące - kiedy otwieramy pudła z jakimiś nośnikami i unosi się nad nimi, prócz kurzu, taki jeden wielki znak zapytania. $\mathrm{Z}$ doświadczenia wiemy, że tam może być wszystko. Chcielibyśmy, oczywiście, żeby materiały były ładnie poukładane i poopisywane: taśma $\mathrm{A}$ jest $\mathrm{z}$ miejscowości $\mathrm{A}$, taśma $\mathrm{B} \mathrm{z}$ miejscowości $\mathrm{B}$, wiemy że to było nagranie zrobione $\mathrm{w}$ takim a nie innym roku, miesiącu, dniu itd. Bardzo często takich danych jednak nie ma i my musimy je rekonstruować z kontekstu. Jest to bardzo skompilowany, czasochłonny i wymagający benedyktyńskiej pracy proces, w którym my te informacje uzyskujemy. Wyobraź sobie, że ktoś, nie wiadomo kto, śpiewa na taśmie $\mathrm{nr}$ 1, ale dopiero na taśmie $\mathrm{nr}$ 1o pada jakieś nazwisko, i my wracamy wtedy do taśmy $\mathrm{nr}$ 1, oraz kolejnych taśm, i po barwie głosu próbujemy ustalić, czy to jest ta, czy inna osoba. Może się wydawać, że to nie ma większego znaczenia, ale z punktu widzenia badawczego i rzetelnego opracowania zbiorów jest to niezwykle istotne, bo takie drobne elementy budują tradycje i pomagają 
odkryć pewne jej ścieżki i historie ludzi. Praca ze źródłami jest więc początkiem jakiejś dłuższej historii, której koniec trudno przewidzieć. A więc na twoje pytanie, wbrew pozorom, dość trudno udzielić prostej odpowiedzi. Jeżeli nawet wiemy, że mamy w danym zbiorze 50 czy 500 taśm, to też do końca nie możemy przewidzieć, ile czasu potrwa ich opracowywanie, co zresztą często utrudnia też wnioskowanie o fundusze. Czasami okazuje się np., że część nagrań to kopie, kompilacje z innych źródeł, które należałoby odnaleźć. A z drugiej strony często zdarza się taka sytuacja, że właściciel nośników pamięta i zapewnia, że robił jakieś cenne nagrania, przy odtwarzaniu okazuje się jednak, iż ktoś nieopatrznie je skasował albo nagrał na taśmie coś innego...

PG: No właśnie, warto zwrócić uwage, że rola takiego repozytorium fonograficznego jak Etnofon nie sprowadza się jedynie do gromadzenia i udostępniania utworów muzycznych. Materiały dźwiękowe, z jakimi mamy tu do czynienia, zawierają bowiem często znacznie szerszy zasób informacji, który można by chyba określić jako pejzaż dźwiękowy dawnej wsi, a niekiedy nawet utrwalony w amatorskich nagraniach swoisty pejzaż kulturowy.

JJ: Tak. I tu rysuje się kolejna bardzo ciekawa perspektywa badawcza. Jeżeli jakiś wykonawca na jednej stronie kasety ma nagrania swojej kapeli ludowej, a na drugiej nagrania zespołu Modern Talking, dla mnie to też jest jakiś dokument historyczny. Jest to element układanki, która buduje pewien obraz człowieka, muzyka, twórcy ludowego lub jego najbliższego otoczenia, w kontekście konkretnego czasu i stanu kultury, np. tego co nadawało radio, co pokazywała wtedy telewizja. Tak więc my niczego nie pomijamy i nie kasujemy, tylko archiwizujemy w zasadzie całość, wraz z kontekstem. Problem pojawia się w momencie tworzenia systemu do archiwizacji takich materiałów. Chcielibyśmy, ale w tym momencie jeszcze nas na to nie stać, żeby stworzyć taki system, który by pokazywał szeroko wszystkie takie okoliczności, nawet nie związane bezpośrednio z kontekstem etnomuzycznym. To jest zresztą perspektywa badawcza, która staje się dość oczywista. Eksplorując zbiory Instytutu Sztuki PAN i przygotowując dotychczasowe wydawnictwa płytowe, w pewnym momencie zdałem sobie sprawę $\mathrm{z}$ drugiej warstwy tych nagrań. Jest tam cała fonosfera minionych lat, gdzie mamy nagrane tykające i bijące zegary, melodyjki pozytywek, szczekające psy, dojarki do mleka, przejeżdżające ciężarówki. To wszystko ma znaczenie kontekstowe.

Jednak ogromnym problemem badawczym jest przy tym metodologia prowadzenia dokumentacji i opisu takich nagrań. Metodologia wypracowana dawniej zakładała docieranie do wykonawców i nagrywanie ich w naturalnym środowisku życia, dotyczyła więc w miarę stabilnej sytuacji. Natomiast ona nie brała pod uwage np. przeglądów i festiwali, które w późniejszym czasie też były nagrywane. Wspomnę chociażby ogromny zbiór Wandy Księżopolskiej, który jest arcytrudny do opracowania, bo jest w nim dużo dokumentów nagranych ze sceny, ale pod względem poznawczym są to bardzo wartościowe rzeczy, 
czasami jedyne nagrania niektórych artystów. A więc różnorodność tych sytuacji, a także duży stopień zażyłości między badaczem a wykonawcami (wtedy często w opisach pomijano sporo informacji, bo „wszystko było wiadomo”) powoduje, że mamy tu mnogość problemów związanych z opisami nagrań albo brakiem takich opisów i wspomnianą koniecznością ich rekonstruowania.

PG: Etnofon to projekt, który można umieścić w rozwijającym się dynamicznie nurcie humanistyki cyfrowej. Czy mógłbyś powiedzieć coś więcej na temat tych najnowszych rozwiązań technologicznych, które są przez was stosowane.

JJ: Tak naprawdę największym wyzwaniem Etnofonu - podobnie jak wielu projektów etnomuzykologicznych związanych w typologizacją materiałów i próbą tworzenia antologii - jest to, że próbuje on zinwentaryzować coś, co w rzeczywistości jest niezwykle trudne do zinwentaryzowania. Jak wiadomo, w folklorze mamy do czynienia ze zjawiskiem wariantywności i poszczególne utwory muzyczne czy słowne istnieją nierzadko w setkach wariantów, które dość trudno zidentyfikować. Przykładowo, jedna pieśn jest śpiewana przez wiele osób w wielu miejscach. I my wiemy, że jest to jeden wątek muzyczny, ale mamy problem, jak odnaleźć jego warianty w tak ogromnym zasobie materiałów. I tu pojawia się nowa perspektywa związana z rozwojem technologii cyfrowych i sztucznej inteligencji. Instytut Sztuki PAN bierze udział w pracach związanych z wykorzystaniem sztucznej inteligencji do wyszukiwania w nagraniach wariantów poszczególnych melodii. W związku z tym równolegle do Etnofonu zaczynamy projekt polegający na tym, że przez najbliższe lata będziemy wytwarzali też nowe nagrania, które posłużą m.in. do tego typu analiz. Chcemy rozpocząc taką drugą akcję zbierania folkloru muzycznego. Będzie to dobrze wyposażone studio mobilne, dzięki któremu chcemy, jeżdżąc po Polsce, wytworzyć pewien korpus źródeł, oparty na tym, co ludzie współcześnie pamiętają, grają i śpiewają, ale spójny pod względem technologii i metod nagrywania. Tak wytworzony testowy zbiór chcemy poddać różnego rodzaju analizom, $\mathrm{w}$ tym również analizom za pomocą sztucznej inteligencji. Wychodzimy bowiem z założenia, że metody cyfrowej analizy materiałów muzycznych muszą być wypracowane najpierw na źródłach kompatybilnych, podobnych i „czystych”. To co się uda wypracować w ten sposób, dopiero potem będziemy wykorzystywać w analizie zasobów archiwalnych. Źródła archiwalne - jak mówiliśmy - są tak różnorodne pod względem techniki nagrań, sposobu opisów i - co też warto podkreślić - skomplikowane pod względem indywidualnej ornamentyki (dzisiaj już w znacznej mierze ludzie nie śpiewają i nie grają tak finezyjnie, jak kiedyś - mam tu na myśli wykonawców wiejskich, a nie nurt rekonstrukcyjny czy rewitalizacyjny), że okazują się „za trudne” w początkowej fazie konstruowania systemów sztucznej inteligencji.

PG: Sztuczna inteligencja identyfikująca warianty poszczególnych melodii to jednak „pieśń przyszłości”, ale dla mnie interesujące są aktualne możliwości 
przeszukiwania bazy. $Z$ punktu widzenia użytkowników, kluczowe znaczenie ma sposób opisu znajdujących się w nim nagrań, czyli zestaw tzw. metadanych. To od nich zależy późniejsza funkcjonalność całego systemu, a zwłaszcza możliwość szybkiego i skutecznego wyszukiwania interesujących nas rzeczy. Stosowany przez was format opisu został wypracowany na gruncie badań etnomuzykologicznych i w moim przekonaniu ma pewne mankamenty, jeśli wziąc pod uwage potrzeby etnologów, folklorystów, literaturoznawców czy historyków. Brak tu np. w opisie takich kategorii jak gatunek utworu czy słowa kluczowe określające treść pieśni. $Z$ czego to wynika i czy jest szansa, że opisy zostaną uzupełnione o tego typu metadane?

JJ: Przede wszystkim każdy, kto tworzy konto w Etnofonie, jest informowany, że system jest w budowie. Zdecydowaliśmy się bowiem, że należy go uruchomić jako prototyp, by jak najszybciej umożliwić eksplorację źródeł, także badaczom spoza naszego Instytutu. To było słuszne, choćby z tego względu, że niebawem stanęliśmy wobec pandemicznej rzeczywistości i dostęp do informacji on-line bardzo ułatwiał komunikację. Ale przyniosło także wiele kłopotów, bo nie każdy rozumie, że jest to rozwijający się projekt i część użytkowników odbiera Etnofon jako gotowe narzędzie, nad którym prace są już zakończone... A to, czym aktualnie dysponujemy, to dopiero około połowa, jeśli nie mniej, z tego, co nadal pozostaje $\mathrm{w}$ fazie projektu na papierze. Zapewne każdy domyśli się, że chodzi tu o ciaggły brak funduszy i fakt, iż komisje grantowe nie rozumieją, że polska nauka wyszła już z epoki pióra i kałamarza. Pocieszające jest to, że dokładnie te same problemy mieli np. wspomniany wcześniej Zborowski czy Roman Zawiliński, których w pierwszej połowie XX w. decydenci akademiccy wyrzucali z pokoju z hukiem i zapewnieniem, że na głupoty - czyli prezentowany wówczas fonograf - pieniędzy nie dadzą.

Ale wracając do twojego pytania, wiele funkcji, o których wspomniałeś, istnieje, ale w fazie albo tworzenia modelu czy testowania mechanizmu, albo wypełniania danymi. Dlatego nie wszystko obecnie jest widoczne. Na przykład w 2021 r. po miesiącach projektowania i testów wdrożyliśmy nowy mechanizm geomappingu. Ale to dopiero wierzchołek góry lodowej, bo przed nami jeszcze długa praca nad przenoszeniem starych danych GEO do nowego środowiska. Pragnę też podkreślić - zresztą mówiłem już o tym na wielu konferencjach, ilustrując to pewnym rysunkiem ze znanego komiksu o Tutusie, Romku i A'Tomku - że nawet w XXI w. nie ma cudownych maszyn profesora T’Alenta, gdzie wrzucisz z jednej strony bałagan, a z drugiej strony wyskoczy porządek...

Zagadnienie, które poruszasz, ma w gruncie rzeczy kilka aspektów. Pierwszy to zdefiniowanie i stworzenie dodatkowych pól opisu oraz wytworzenie stosownych metadanych, które - jak mówiliśmy - często są niekompletne lub w ogóle ich nie ma, albo - jeśli są - wymagają przeniesienia z rękopiśmiennych kwestionariuszy badań terenowych do domeny cyfrowej. To ostatnie zadanie jest też nie lada wyzwaniem, co pokazał wspomniany geomapping, na który udało nam się w tym roku pozyskać niewielkie środki. Okazało się bowiem, że 
dostępne mapy i wykazy miejscowości nie nadają się do opisu takiego zbioru jak nasz, który był tworzony na przestrzeni wielu lat przy zmieniających się podziałach administracyjnych, był ukierunkowany na docieranie do małych miejscowości, z których część przestała istnieć, a jeszcze dodatkowo wiele nagrań było robionych na drodze $\mathrm{z}$ miejscowości $\mathrm{A}$ do miejscowości B. Na potrzeby Etnofonu stworzyliśmy więc specjalną bazę - nawet nie miejscowości, tylko miejsc - ale jej wdrażanie będzie trwało zapewne kilka lat ze względu na niewielką liczbe osób, która przy tym pracuje. I to jest przykład problemów, z jakimi wiąże się dopasowywanie systemu opisu i wyszukiwania materiałów do specyfiki naszych zbiorów.

W pierwszej fazie projektu skupiliśmy się na tych metadanych, którymi dysponujemy. W dalszej kolejności są wytwarzane nowe metadane i od razu sposób ich prezentacji, tesaurusy, słowniki, listy rozwijane itp. To niełatwa praca, przede wszystkim koncepcyjna i interdyscyplinarna. Chodzi tu też o to, by różni użytkownicy bazy wskazali takie kategorie opisu, które byłyby użyteczne z ich punktu widzenia. No i wprowadzanie danych, które po macoszemu zwykło się nazywać „wklepywaniem” - to bardzo nieładne i pejoratywne określenie niezwykle odpowiedzialnej pracy wymagającej kompetencji i benedyktyńskiej cierpliwości. Niewiele osób doświadczyło takiej pracy. Początkowo w tym zakresie próbowaliśmy współpracować także ze środowiskiem niemuzykologicznym, z miłośnikami tradycji. Jednak pojawia się tu charakterystyczne zjawisko: Miło jest jechać w teren i prowadzić badania, ale właściwa praca zaczyna się po powrocie i tu już zwykle nie ma tylu chętnych... Swego czasu pisałem o tym zjawisku w jednym z numerów „Muzyki” ${ }^{2}$. Wszystko to wymaga sporego nakładu pracy, a tym samym zdobycia odpowiednich środków. Wiele wniosków przepada w konkursach, ale szczęśliwie pozyskujemy raz większe, raz mniejsze środki, jednak głównie z Ministerstwa Kultury i Dziedzictwa Narodowego. Nauka - jak wspomniałem - tego typ działania nadal postrzega jako drugorzędne, choć pewną nadzieją jest tu wspomniana humanistyka cyfrowa - dość nowe zjawisko.

Innym przykładem jest kategoria gatunku. Jego określenie może pochodzić od wykonawcy, od kilku wykonawców (tu może paść więcej różnych określeń), ale może też być wskazane przez badacza czy osobę opracowującą nagranie, a te określenia nie zawsze są kompatybilne. W Etnofonie nie chcemy stosować w tym względzie rozwiązań arbitralnych, czyli np. opisywać danego utworu tylko w określony sposób, bo tak „powiedział pan profesor”, choć wykonawca określił go inaczej. Cyfrowa baza danych umożliwia jednak umieszczenie większej liczby określeń na równym poziomie, bez konieczności ich hierarchizowania, natomiast $\mathrm{z}$ odniesieniem do podmiotu klasyfikującego. Ale znów jest to związane $\mathrm{z}$ ogromną pracą potrzebną do ustalenia zestawu takich określeń,

2 Chodzi o artykuł Wspótczesne metody zabezpieczania, opracowania naukowego, udostępniania i rozwoju Zbiorów Fonograficznych Instytutu Sztuki PAN, „Muzyka” 2014, nr 3. Tekst dostępny jest również na stronie Etnofonu. 
uporządkowania ich, stworzenia słownika. Problem polega też na tym, że przygotowując takie listy kategorii opisowych (np. gatunków) powinniśmy uwzględnić dotychczasowe osiągnięcia w tej dziedzinie. Jako etnomuzykolodzy bierzemy więc pod uwage np. wydane do tej pory antologie pieśni ludowych. Okazuje się jednak, że te prace zawierają różne rozwiązania w zakresie klasyfikacji, typologizacji czy opisu materiału, a propozycje te nie zawsze są kompatybilne. Trzeba pamiętać, że przyjęcie jakiegoś rozwiązania w tej kwestii jest brzemienne w skutki i musi być dobrze przemyślane; my podchodzimy do tego odpowiedzialnie, bo traktujemy Etnofon również jako projekt badawczy. I nie jest tak, że chcemy tu przeforsować i wprowadzić jakieś jeden z góry zdefiniowany system opisu. Raczej próbujemy wypracować w tym zakresie rozwiązania kompromisowe, które są konsultowane $\mathrm{z}$ różnymi osobami, także $\mathrm{z}$ twórcami ludowymi. Bardzo często zapraszamy też do konsultacji osoby, dla których folklor jest raczej egzotyczną dziedziną; próbujemy je zainteresować naszymi pracami, a jednocześnie pytamy: Co ty byś z tym zrobił? Jak byś szukał materiałów? Czego ci tu brakuje?

Niezależnie od środków, jakie udaje się zdobyć w ramach grantów na realizację konkretnych projektów, trwają systematyczne prace nad różnymi kategoriami opisu źródeł i różnymi możliwościami ich przeszukiwania, np. po incipitach pieśni czy w formie wyszukiwania pełnotekstowego (w tym zakresie pojawia się zresztą ogromne wyzwanie związane z formami językowymi, dialektami, zapisami fonetycznymi, półfonetycznymi), i mam nadzieję, że niebawem nastąpi tu wyraźny jakościowy przełom. Mam też takie marzenie - i myślę, że kiedyś je zrealizuję - żeby Etnofon posiadał coś takiego jak redakcja społecznościowa. Chodzi o to, żeby każdy użytkownik miał możliwość komentowania i uzupełniania udostępnianych przez nas źródeł, zwłaszcza w zakresie kontekstowym. To byłby taki zdalny wywiad terenowy. Ale to znów wymagałoby czuwania nad dostarczanymi treściami i ich porządkowania, choć wiele można by tu zautomatyzować.

Wracając do mankamentów, o których wspomniałeś, trzeba powiedzieć, że pod tym względem mieliśmy ogromne wątpliwości i być może nawet naraziliśmy się nieco środowisku naukowemu. Problem polegał na tym, że albo będziemy „w nieskończoność” cyzelować dane, poprawiać opisy, udoskonalać metody wyszukiwania, albo pokażemy to $\mathrm{w}$ takim stanie, w jakim aktualnie jest. W tej sprawie pojawia się dużo głosów, często w postaci telefonów czy maili. Zarysuję przykładową, ale zarazem modelową sytuację. Dzwoni pani albo pan nauczyciel z jakiejś bardzo małej miejscowości i mówi tak: „Dzień dobry, jestem nauczycielem z miejscowości X. Bardzo przepraszam, że zwracam państwu uwage, ale wy w Polskiej Akademii Nauk powinniście wiedzieć, że nazwa mojej rodzinnej miejscowości jest zapisywana przez „u” a nie „ó”, bo to jest wyjątek”. Takie sytuacje dotyczą nie tylko nazw miejscowości, ale też np. wykonawców, których nazwiska zostały zapisane nieprawidłowo. Opublikowanie bazy danych w takiej niedoskonałej postaci, gdzie większość opisów powstawała „Z autopsji”, jest więc wielce ryzykowne, może bowiem wywołać sprzeciw niektórych użyt- 
kowników. Druga strona medalu jest taka, że są środowiska, które zarzucają nam, że nic nie publikujemy czy wręcz w ogóle nic nie robimy; mówią, że Instytut najchętniej by wszystko zamknął i niczego nie udostępniał. Trzeba więc wyważyć opinie, bo są tu różne punkty widzenia.

PG: Właśnie! Sprawą, która budzi chyba największe kontrowersje, jest dostępność nagrań umieszczanych w Etnofonie. Niektórzy - jak sam wspomniałeś - zarzucają wam, że blokujecie dostęp do nagrań. Przywołuje się tu koncepcje „otwartej nauki”, twierdząc, że efekty prac prowadzonych przez publiczną instytucję za publiczne pieniądze powinny być dostępne bez ograniczeń dla wszystkich obywateli. Dlaczego więc dostęp do Etnofonu jest limitowany, wymaga założenia konta i podpisywania specjalnych umów?

JJ: Projekt Etnofon polega - jak powiedzieliśmy - na agregowaniu różnych zbiorów. W chwili obecnej od znacznej większości instytucji dysponujących tymi zbiorami nie mamy zgody na publikowanie ich nagrań w otwartym dostępie i jest to uzasadnione różnymi czynnikami, np. obowiązującym stanem prawnym czy planami wydawniczymi instytucji, zwłaszcza tych naukowych. To co udało nam się wypracować na tym polu (jednym $\mathrm{z}$ celów projektu jest też badanie aspektów prawnych związanych z udostępnianiem nagrań), to udostępnianie tych nagrań na określonych zasadach. Krótko mówiąc, dostęp do nich jest możliwy w zasadzie dla każdego, pod warunkiem że ten ktoś się do nas zwróci i określi, co i do czego jest mu potrzebne. Jeśli zostaną spełnione wymagania regulaminowe oraz podpisana stosowna umowa określająca pola eksploatacji i odpowiedzialność korzystającego, nie ma przeszkód w dostępie do pełnej informacji i obiektów.

W tej chwili użytkownicy mogą korzystać z Etnofonu za pomocą dwóch rodzajów kont: podstawowego i zaawansowanego/rozszerzonego. Konto podstawowe daje możliwość przeszukiwania wszystkich rekordów w naszej bazie oraz dostęp do próbek wielu nagrań. To rozwiązanie popularne np. w serwisach internetowych z muzyką. Takie konto każdy może założyć samodzielnie za pomocą kilku „kliknięć”; nie wiąże się to oczywiście z żadnymi opłatami. Założenie konta wiąże się natomiast $\mathrm{z}$ koniecznością podania pewnych danych, $\mathrm{np}$. imienia i nazwiska oraz adresu e-mail. Ważne jest dla nas również, czy osoba rejestrująca się reprezentuje środowisko naukowe, artystyczne czy inne. Te informacje pomagają nam planować i projektować dalsze rozwiązania nie tylko w Etnofonie, ale i w szerszej działalności naukowej, a także formułować wnioski i popierać je konkretnymi danymi liczbowymi. Pamiętam, że kilkanaście lat temu na podstawie analizy zachowanych ksiagg interesantów (tam wpisywano także podobne dane) przygotowałem statystykę za ostatnie kilka dekad, która pokazała, jak bardzo zmienił się i spolaryzował profil użytkowników naszych zbiorów, co jest także znakiem przemian kulturowych. Współczesne analizy użytkowników są też istotne ze względu na nasze sprawozdania $\mathrm{z}$ działalności naukowo-badawczej. 
Konta zaawansowane są tworzone przez nas na zasadzie zmiany statusu użytkownika, który wykaże, że dostęp do wybranych obiektów oraz metadanych jest mu potrzebny jako źródło do badań naukowych. Nadanie statusu użytkownika zaawansowanego wymaga podpisania wspomnianej umowy z Instytutem Sztuki PAN i umożliwia dostęp do pełnych wersji wybranych nagrań, a także dostęp do danych, które nie mogą być udostępniane każdemu, np. ze względów prawnych. Jeśli użytkownik naukowy potrzebuje także dostępu do zasobów zagregowanych (to znaczy tych, których Instytut nie jest właścicielem), wówczas umowa jest trójstronna, czyli dochodzi właściciel zagregowanego zbioru.

Ponieważ ostatnio prócz naukowców czy artystów-badaczy pojawiło się wiele nowych grup zainteresowanych naszymi zbiorami, które kwestionują zasadność procedury zmiany profilu użytkownika, spotykamy się niejednokrotnie z opiniami, że zbiory te powinny być otwarte, czyli dostępne dla wszystkich, bez żadnych ograniczeń i kontroli. Dokładnie do tego dążymy, przy czym, z uwagi na stricte naukowy charakter naszej instytucji, kolejność prac jest następująca: najpierw opracowujemy merytorycznie pewien obszar zasobu (np. jakiś region), wydajemy materiał w formie książek, płyt, multimediów, artykułów itp. i na końcu otwieramy dostęp. Tak robią też podobne instytucje za granicą, które mają plan swych działań, a zbiory nie są dla nich „balastem” lecz podstawą do aktywności naukowo-edytorskich.

Trzeba pamiętać, że Etnofon jest bazą źródeł, które są dopiero punktem wyjścia do dalszych badań, a ich efekty przybierają różną formę, np. wspomnianych wcześniej publikacji. Jest to zatem niejako zbiór „rękopisów dźwiękowych", które - istniejąc w postaci surowej, rozproszonej, bezkontekstowej - czekają na opracowanie. Wychodzimy przy tym z podstawowego założenia, że takich nieopracowanych zasobów nie powinno się udostępniać publicznie. Nasze zbiory są więc systematycznie, planowo opracowywane i służą jako źródła i materiały dla wielu projektów naukowych oraz edytorskich. Duży nacisk kładziemy na prace wydawnicze o charakterze popularnonaukowym i publikowanie płyt z książkami, w których znajdują się obszerne, kontekstowe opracowania materiałów muzycznych. Od niedawna zaczęliśmy stosować też rozwiązanie, że na płytach DVD umieszczamy pliki w formacie $\mathrm{MP}_{3}$, co pozwala zmieścić na nich dużo więcej nagrań. Trzeba przy tym podkreślić - bo może nie wszyscy mają tego świadomość - że te wydawnictwa płytowe są również publikowane na stronie internetowej Etnofonu. W zakładce „Wydawnictwa” są dostępne on-line wersje wszystkich naszych płyt, zawierające pełne wersje nagrań (w tej chwili w liczbie ok. 2 ooo) łącznie z bookletami. Zatem im więcej nagrań wydamy, tym szerzej będzie otwarty Etnofon. Tyko przy takim podejściu mamy pewność, że publikowane przez nas obiekty i dane są rzetelne i nie wprowadzą kogoś w błąd. Zresztą informujemy o tym użytkowników, którzy zakładając konto, widzą następujący komunikat: „Udostępniono tylko te obiekty i dane, których ujawnianie jest zgodne z obowiązującymi przepisami prawa. Obiekty pozostające w planach wydawniczych oraz w autorskim opracowaniu zostaną udostępnione po ich publikacji. Większość danych ma charakter poglą- 
dowy a ich pełną reprezentację wraz z kontekstem merytorycznym Użytkownik znajdzie w wydawnictwach książkowych i płytowych IS PAN”.

Aby tę sytuację lepiej zobrazować wyobraźmy sobie, że np. mając taką technologię jak dziś, zrezygnowano by kiedyś z całej pracy redakcyjnej przy edycji Dzieł Wszystkich Oskara Kolberga, zeskanowano rękopisy i zakończono projekt wraz z ich udostępnieniem w jakimś repozytorium. Można i tak. Ale nasze doświadczenia wskazują, że lepsze są inne rozwiązania. Podam jeden przykład. Spotkaliśmy się niejednokrotnie z taką narracją: „No, w latach 50. to wy przyjechaliście do nas i ukradliście (sic!) nam te nagrania (w sensie, że "wyrwaliście« je od ludzi), zawieźliście do Warszawy, schowaliście i teraz nie chcecie dać. Chcecie żeby płacić, żebyśmy pomogli zorganizować pieniądze na wydawnictwo płytowe!”. Zwykle do podobnych stwierdzeń odnosimy się następująco: „No dobrze, ale czy nie wydaje się Państwu, że przechowanie przez 70 lat nagrań, które dzisiaj brzmią po prostu świetnie, wzorcowo akustycznie (a mówią, że wszystko co niezdigitalizowane $\mathrm{w}$ pył się obraca), nic nie kosztuje w zakresie zarówno finansowym, jak i administracyjnym?” Zazwyczaj następuje wówczas refleksja. Ale to nie koniec historii, bo później zaczyna się dyskusja nad sensem wydawania publikacji i wyboru nagrań w sytuacji, gdy mamy internet, do którego wszystko można „wrzucić”. I dopiero gdy zaczynamy pracę nad płytą, wielu regionalistom otwierają się oczy, ponieważ mają dostęp do tych wszystkich nagrań, które „ukradliśmy” im w latach 5o. Słuchają ich i nagle: „O Boże! Ale przecież to jest $\mathrm{z}$ sąsiedniego regionu! To nie nasze! A nagrane u nas... A to drugie nagranie też nie jest nasze. A trzecie jest brzydkie - my myśleliśmy, że $\mathrm{X}$ to miał głos jak dzwon... A o Y pisali, że był wirtuozem, a on tu się myli... A piąte to jest $Z$ - ja go pamiętam, on znał wiele pieśni, a tu śpiewa tylko sprośne przyśpiewki, aż uszy więdną... A tu ktoś śpiewa pieśni, które mogą być odczytane jako ubliżające jakiemuś narodowi”. Ja wtedy mówię: „To jest wasz region, tak to zostało utrwalone - pakujemy to wszystko do internetu”. I tu następuje zwrot nastawienia i przyznanie, że jednak dobrze zredagowana, obiektywna antologia pokaże esencję, która będzie zarazem swego rodzaju „instrukcją” do poruszania się po pełnym, trudniejszym w odbiorze zasobie.

Warto dodać, że w tym miejscu dotykamy też kwestii metod postępowania przyjętych $\mathrm{w}$ momencie tworzenia poszczególnych zbiorów. To, że w danym zasobie dominuje jakaś pieśni, nie zawsze odzwierciedla rzeczywistość, bo może być to choćby efekt szczególnego zainteresowania badacza danym wątkiem. I teraz powstaje pytanie, czy za 100 lat ktoś, nie znając kontekstu i przyjętej w konkretnym przypadku metody zbierania materiału, mylnie nie stwierdzi, że w danym rejonie wyjątkowo ulubiono sobie ten albo inny utwór.

Ale jest jeszcze druga strona medalu, czyli pokusa (zwłaszcza dla regionalistów) by poprzez taki a nie inny wybór materiałów „nagiąć” historyczną rzeczywistość. W ostatnich latach nastąpiła bardzo silna regionalizacja; ludzie zaczęli myśleć „małymi ojczyznami”, a odrębność kulturowa jest atrakcyjna i lepiej finansowana. Jeszcze w drugiej połowie XX w. nie było tego tematu na taką skalę (choć były wtedy też inne tendencje i przejaskrawienia, o których trzeba 
pamiętać), a granice pieśni, stylu, gwary czy nawet języka i repertuaru nie były aż tak jaskrawo wyznaczane. Ludzie śpiewali, co znali, migrowali, a presja festiwali (choć ruch sceniczny przecież trwał już od początku XX w.) nie była aż tak silna, by odbijać się na jeszcze żywej tkance praktyki muzycznej. Robione wtedy nagrania to była taka migawka ówczesnej autentycznej kultury danego miejsca. Dzisiaj przedstawiciele tych regionów wyobrażają sobie, że jeżeli coś w Instytucie Sztuki PAN było nagrane 70 lat temu, to to jest absolutnie to, do czego oni dążą regionalistycznie. I rzeczywiście, te nagrania prezentują pewną prawdę, ale ta prawda nie jest niestety tym obrazem, do którego dążą niektóre grupy regionalne. Czasem w konfrontacji z dokumentem trochę im ręce opadają, bo to jest coś innego, niż to, czego się spodziewali. Z kolei nie brak też postaw bezrefleksyjnego zachwytu „surowością” czy „siermiężnością” dokumentu i nietrafioną lub przejaskrawioną „rekonstrukcja” czy „rewitalizacją” tradycji albo też prób udowadniania śmiałych tez za pomocą jednostkowego egzemplum. Prawda dokumentalna zawsze okazuje się nieoczywista. Zatem poruszanie się po setkach tysięcy nagrań dokumentalnych bez przewodnika może prowadzić do skrajnych postaw i dlatego dobrze, że takie zasoby są w znacznej mierze pod kuratelą instytucji naukowych. Niedawno, zwiedzając jedno z tatrzańskich muzeów, przeczytałem na ekspozycji takie słowa, zacytowane z memoriału Ochrona Tatr z 1913 r.: „Udostępnienie Tatr sprawiło, że coraz znaczniejsze zastępy gości przeciągają przez góry, niosąc ze sobą bezmyślność i beztroskę w używaniu swobody”.

Tak więc udostępnienie zasobu (zwłaszcza źródeł tworzonych w celu prowadzenia prac badawczych i wydań naukowych antologii), który nie został w pełni opracowany i opublikowany krytycznie, może wiązać się z pewnym ryzykiem. Brak punktu odniesienia w postaci popartego rzetelnymi badaniami opracowania sprawia, że wielu - zwłaszcza nienaukowych - użytkowników ma spore trudności w poruszaniu się po tym „oceanie źródeł”. Potwierdzeniem słuszności takiego poglądu są nasze doświadczenia współpracy ze specjalistami badającymi poszczególne regiony lub pochodzącymi z nich twórcami, wrośniętymi w daną kulturę lokalną, którzy podczas pracy nad publikacjami pomagają zhierarchizować dostępny materiał, oddzielić „ziarno od plewy”. Mamy również doświadczenia sytuacji, gdzie niemal w ostatniej chwili zapobiegliśmy błędnym interpretacjom, które wynikały właśnie $\mathrm{z}$ niezbyt rzetelnego przestudiowania kontekstu. Z drugiej strony, gdyby tak wszystko „puścić na żywioł”, powstałaby interesująca sytuacja kulturotwórcza, ale nie wiem, czy w czasach, gdy wspomniany regionalizm tak silnie kształtuje lokalne odrębności jako antidotum na globalizacje i w cenie jest „wierność tradycji”, taka postawa byłaby słuszna. Jak zwykle wszystko zależy od punktu widzenia...

Zatem reasumując, Etnofon to repozytorium stanowiące rodzaj zbioru „rękopisów”, które należy poddać „redakcji”, a otwieranie zasobu pozostającego w opracowaniu wymaga od nas dużej ostrożności, uwagi i odpowiedzialności, by - korzystając z rozwijających się dynamicznie rozwiązań technologicznych - uchronić się przed popełnieniem dziejowego zaniedbania. Etnofonu nie po- 
strzegam więc jako rodzaju etno-fono-Googla. I choć chciałbym, by technologicznie też był tak zaawansowany, to nie życzyłbym sobie efektu, z jakim mamy do czynienia w przypadku tej najpopularniejszej wyszukiwarki, która sprawia, że wiele osób zamiast iść do lekarza-specjalisty, stawia sobie diagnozę samodzielnie na podstawie lektury tekstów znalezionych w sieci, a wielu uczniów zamiast sięgnąc do wydawnictw PWN, czyta popularne blogi lub fora dyskusyjne. Pamiętajmy, że Google ma na celu eksplorację bodaj najbardziej rozproszonego i różnorodnego środowiska, jakim jest internet, Etnofon zaś ma być rodzajem specjalistycznej przystani dla kogoś dryfującego w oceanie rozproszonych informacji.

Chciałbym jeszcze na marginesie podkreślić, iż ta perspektywa jest oparta na studiach historii polskiej etnofonografii. Historia ta pokazuje, że mimo wspomnianych na początku naszej rozmowy strat wojennych wiele dóbr nauki i kultury przetrwało właśnie dzięki publikacjom i ich powielaniu. Pomimo że od niemal 20 lat zajmuję się digitalizacją i przenoszeniem świata kolekcji analogowych w świat nowych mediów, nadal jestem przekonany, że internet i technologie cyfrowe nie są absolutnie żadnymi gwarantami wieczystego zachowania dokumentów przeszłości. Zresztą wielokrotnie pisałem już na temat mylenia archiwizacji z digitalizacją oraz złudnego pokładania nadziei w tej ostatniej jako skutecznej formie zachowania dziedzictwa. Digitalizacja to dobry sposób na tworzenie narzędzi dostępu do informacji, ale nie rozwiązanie problemów $\mathrm{z}$ ich trwałą archiwizacją.

Ale wróćmy do tematu udostępniania. Wbrew pozorom sprawa otwartego dostępu do tego typu dokumentacji nie jest taka prosta i ma różne aspekty. Musimy pamiętać, że zbiory te były tworzone nie w celu ich publikacji fonograficznej, ale ściśle na potrzeby nauki. Zapewniano o tym nagrywanych wykonawców i zastrzegano - w odpowiedzi na ich pytania - że dokumentaliści nie są z radia ani telewizji i materiał nie będzie nigdzie emitowany, tylko wykorzystany do sporządzenia transkrypcji muzycznej i tekstowej. Nie podpisywano w związku z tym z wykonawcami żadnych umów, zgód, porozumień, które dziś bardzo by ułatwiły (lub utrudniły) zadanie. Kiedy Jadwiga Sobieska w latach 7o. XX w. planowała wydanie materiału na płycie, powracano do wybranych wykonawców i dokonywano osobnych nagrań specjalnie dla celów wydawniczych, stosując także inną technologię.

Trzeba też uczciwie przyznać, że my jako etnomuzykolodzy często przekonywaliśmy śpiewaków czy instrumentalistów, że robione przez nas nagrania nie będą publikowane, ponieważ chcieliśmy uzyskać efekt otwartości i prawdomówności wykonawcy, próbowaliśmy doprowadzić do sytuacji intymnej, w której ktoś się otworzył, a te mikrofony pracowały w tle. Cóż... sam uczestniczyłem $\mathrm{w}$ tym procederze 20 lat temu w imię uzyskania cennego, wiarygodnego źródła-dokumentu i wtedy nie śniłoby mi się, że dwie dekady później, w dobie internetu stanę przed takim dylematem. Powiem więcej, na nagraniach archiwalnych czasami słychać nawet prośby wykonawców o to, by nie publikować nagrań, a nawet, żeby ich nie nagrywać, bo chcą wyrazić coś poufnego, intymnego, 
osobistego. A eksploracja zbiorów niejednokrotnie pokazuje, że taśma nadal się kręciła... Czy w tej sytuacji my mamy prawo publikować takie materiały?

Sytuację komplikuje fakt, że jeszcze kilkadziesiąt lat temu nikt nie spodziewał się, iż - relatywnie niedługo - pojawi się możliwość tak łatwej publikacji nagrań na płytach, w plikach, w sieci... Przyszło nam zatem odpowiadać za ten wyjątkowy zbiór w szczególnym czasie. Trudność polega na tym, że to nie są nagrania odgłosów przyrody lub efektów dźwiękowych, lecz żywych ludzi - ludowych artystów, którym zawsze przysługiwało prawo do decydowania o powierzonych komuś swoich dobrach intelektualnych - w tym wypadku wykonaniach pieśni lub melodii. Trzeba przy tym podkreślić, że dokumentaliści starali się docierać zawsze do informatorów najciekawszych, najwybitniejszych, często wskazanych przez lokalną społeczność właśnie jako „miejscowi artyści”. Ponieważ problem rozpowszechniania nagrań dokumentalnych muzyki tradycyjnej nie był dotąd w ogóle analizowany na gruncie prawnym, razem z Nicholasem Gazalem napisaliśmy na ten temat obszerny artykuł, który ukazał się w tomie Polska muzyka tradycyjna - dziedzictwo fonograficzne (t. 2, Warszawa 2019). Nie chcę streszczać omawianych tam szczegółowo kwestii - zapraszam do lektury tekstu, który jest dostępny na stronie Etnofonu - powiem tylko, że opracowanie to definiuje i porządkuje wiele zagadnień, choćby prawa i obowiązki instytucji posiadających tego typu zbiory. Warto bowiem np. wiedzieć, że w świetle obowiązujących przepisów Zbiory Fonograficzne Instytutu Sztuki PAN to nie jest archiwum (Archiwum PAN to inna jednostka, która znajduje się w Pałacu Staszica na Krakowskim Przedmieściu), a często mylnie za takie właśnie są uważane i w związku z tym oczekuje się, że wszystkie jego zasoby powinny być publicznie dostępne. Jednak zgodnie z ustawą materiały zgromadzone w naszym Instytucie stanowią bazę źródeł do badań prowadzonych przez tę właśnie jednostkę naukowo-badawczą, a tym samym nie muszą - a nawet nie powinny - być upubliczniane przed ich opracowaniem i wydaniem przez macierzystą jednostkę. Jak podkreśliłem wyżej, nasza praktyka, podyktowana planem stopniowego otwierania zasobu w szerszym kontekście społecznym (nie tylko dla nauki), przełamuje tę zasadę.

Podsumowując, można powiedzieć, że nawet jeśli minął już przewidziany prawnie czas ochrony nagrań, czyli 50 lat od momentu ich zarejestrowania, i mogą one trafić do domeny publicznej (zwykle, niestety, błędnie pojmowanej), nie znaczy to, że koniecznie muszą. To kurator zbiorów ma obowiązek podjęcia w tej sprawie odpowiedzialnej decyzji, a również wykonawca (lub jego spadkobiercy) mogą mieć w tej sprawie coś do powiedzenia.

PG: We wspomnianym przez ciebie artykule szczególnie zainteresowały mnie pewne kwestie etyczne związane $\mathrm{z}$ udostępnianiem nagrań archiwalnych. Okazuje się, że często nawet jeśli pod względem prawnym ich sytuacja jest jasna, to publikacja w otwartym dostępie może budzić poważne wątpliwości. Czy mógłbyś nieco szerzej omówić tego typu problemy i podać jakieś przykłady? 
JJ: Częściowo była już o tym mowa, gdy wspominałem o prośbach wykonawców, by ich nie nagrywać lub zapewnieniach, że nagrania nie będą publikowane, ale możemy to jeszcze uszczegółowić i rozwinąć. Chodzi tu bowiem również o intersubiektywną ocenę estetycznej jakości tych nagrań. Pozwolę sobie przytoczyć taki przykład: Syn jednego z instrumentalistów grających w pewnej kapeli odmówił nam, niestety, współpracy w jednym z projektów tylko z tego powodu, że wcześniej opublikowaliśmy (zgodnie z prawem) na płycie nagrania jego ojca, które on - po zapoznaniu się z publikacją - uznał za niedobre pod względem muzycznym. To region, w którym muzyka instrumentalna bardzo się sprofesjonalizowała i dziś dąży się tam, by wykonywać ją dobrze, czysto i estetycznie, zaś opublikowane przez nas nagranie wykonane było w „starym stylu”. Widzimy zatem, że kryteria oceny współczesnych muzyków grających repertuar tradycyjny mogą być diametralnie różne od kryteriów przyjętych przez badaczy, postrzegających źródło jako dokument historyczny.

Poza tym wiele wykonań, choć można je stranskrybować i wykorzystać $\mathrm{w}$ różnych opracowaniach, $\mathrm{z}$ estetycznego punktu widzenia nie nadaje się do publikacji. Dobrym przykładem są materiały, które weszły do wydawnictw z serii Polska pieśn i muzyka ludowa. Mamy tam bardzo dużo dobrze opracowanych transkrypcji, ale $\mathrm{z}$ wielu powodów nie każdy utwór, który został tam opublikowany, może być udostępniony w formie nagrania, np. materiał cenny merytorycznie mógł zostać podany przez wykonawcę we fragmentach (ze względu na stan pamięci) albo też w taki sposób, że możemy przypuszczać, iż wykonawca nie życzyłby sobie publikacji takiego nagrania. Pamiętajmy o takich kwestiach jak chwilowa niedyspozycja czy zły stan zdrowia śpiewaków lub instrumentalistów. A w ekstremalnych przypadkach naprawdę docierano do ludzi w ostatniej chwili... To były wyjątkowo trudne sytuacje, a oni zgadzali się na udzielenie odpowiedzi na pewne pytania, zanucenie czegoś - czasem było to nawet wzruszające wspomnienie dawnych lat - ale czy od razu musimy to publikować?

Współcześnie również mamy do czynienia z sytuacjami, które wywołują refleksję nad podejściem do publikacji materiałów historycznych. Tuż przed pandemią robiliśmy typowo dokumentacyjne nagrania w pewnym regionie. Przy podpisywaniu umów, wykonawcy byli informowani, że wyrażają zgodę na publikacje zarejestrowanego materiału, m.in. w naszym repozytorium, i niemal we wszystkich przypadkach osoby, które zostały nagrane, zastrzegały, że chcą mieć możliwość odsłuchania materiału i prawo do ostatecznej decyzji, które z nagrań będą mogły być upubliczniane, a które nie. Mając takie doświadczenie $\mathrm{z}$ własnych badań w terenie, które staram się jakoś przetransponować w przeszłość, nie mogę zakładać, że w przypadku dawnych nagrań można publikować wszystko bez ograniczeń.

Wróćmy jeszcze - w kontekście poszanowania twórcy - do wydawanych przez nas serii płytowych, które stanowią również swego rodzaju hołd złożony wykonawcom. Są tam wybrane nagrania najlepsze, najbardziej reprezentatywne, również pod kontem ich jakości estetycznej, wykonawczej. Wkładamy sporo pracy badawczej w rekonstrukcję dźwięku i robimy z tych nagrań wzorcowe 
„próbki”, które idą w świat. Ci, w większości przypadków nieżyjący już, śpiewacy czy muzycy są przez nas traktowani jak artyści - nawet celowo w Etnofonie rejestr wykonawców nazwałem rejestrem artystów. I w tym przypadku - choć wykonawcy nie byli informowani, że są nagrywani „na płytę” - mamy czyste sumienie, bo dołożyliśmy wszelkich starań, by te nagrania były jak najlepsze.

Oczywiście wszystkie te problemy i wątpliwości nie powinny prowadzić do zablokowania możliwości udostępnienia nagrań przez internet. Ale to udostępnianie powinno się odbywać na określonych zasadach, które będą w jakiś sposób uwzględniały takie problematyczne kwestie. Jesteśmy świadomi, że Etnofon to trudne wyzwanie, chodzi tu bowiem o zaprojektowanie i wykonanie w świecie cyfrowym szczególnego rodzaju historycznego dokumentu etnomuzycznego i etnofonograficznego, który kreuje diametralnie inną rzeczywistość i kształtuje pewne nieznane wcześniej postawy nowych generacji użytkowników szukających w sieci także dóbr kultury. 